\title{
SYSTEMS AND PROCESS AS A TREND IN URBAN MOBILITY PROJECT
}

\author{
Celso Hashisaka Junior and Rosária de Fátima Segger Macri Russo \\ Universidade Nove de Julho - UNINOVE, Brazil
}

\begin{abstract}
Society's transformations increasingly demand that projects be innovative and sustainable. The concept of smart cities highlights these aspects and their presence is essential in many cases, such as urban mobility that affects all citizens. Our research aims to identify innovation trends based on the study of patents with applications in urban mobility. We use technometry, which applies the statistical analysis of data resulting from the patent data mining process. Based on 199 patents, we identified the main factors for these projects: communication technology, specialized and adaptive systems and processes. The potential for frugality, given patent rights, is highlighted in this case. Finally, in an increasingly connected and dynamic social context, results that align with the digital transformation that we live in modern society.
\end{abstract}

\section{KEYWORDS}

Urban Mobility, Project, Innovations’ Trend, Technology, Patent

\section{INTRODUCTION}

According to the United Nations (UN), $70 \%$ of the world population lives in cities, that is, predominantly urban areas. Dias et al. (2018) reports the importance of transportation in cities, assessing data from this activity for urban emissions inventories. The increase in distances, number and travel times creates a public policy problem, influencing people's quality of life (Machado and Piccinini, 2018). Urban dynamics define how people occupy areas of the city (Forrester, 1970), and this logic helps to create intelligence in cities. The efficient and sustainable use of resources, infrastructure, information systems and services to be provided, providing conditions for citizens to change (Hashisaka and Patah, 2018), and thus a smart city emerges.

The urban mobility is one of the smart cities' dimensions, and the technology shows a trend of technological evolution traffic control and management of transport services (Giffinger and Gudrun, 2010; Pellicer et al, 2013). The development and improvement of 5G connection technologies, wifi, and mobile devices create conditions to develop sustainable urban mobility solutions (Gakenheimer, 1999). Researchers and funders invest in research that can indicate trends for the development of technology and improvement of urban mobility, using technologies such as cloud computing, internet of things, among others.

In addition, there are specific lines of credit, such as those of the Inter-American Development Bank (IDB) and the Banco Nacional de Desenvolvimento Econômico e Social (BNDES), to develop sustainable and innovative urban mobility (Moreira et al., 2016). In Brazil, the legislation determined a National Urban Mobility Policy in 2012, defining that cities with more than 20 thousand inhabitants need to prepare their mobility plans (Moreira et al., 2016). Thus, there are opportunities for the use of information and communication technology (ICT), innovations in urban mobility systems and processes.

In order to identify trends in innovations for urban mobility, we see in patents a relevant input to observe investments and efforts of inventors. The problems of urban mobility call the attention of academics and professionals, in studies that address the theme (Sarkheyli and Sarkheyli, 2019), but few deals with patents. In general, we find studies such as bibliometrics. Knowledge of the frontier of public management, urban planning, ICT is complex, and its technological advances seek to improve the services provided to citizens (Santos, 2017; Bencke and Perez, 2018). Thus, inventions can assist this development, and databases and software specialized in patent data mining become useful for research methods or procedures (Ferraz, et al., 2016). Our research aims to study technologies and processes, adopting technometry as a research method, which uses statistical techniques to study the evolution of technologies (Coccia, 2005). 
The results demonstrate that technological products tend to develop sustainable transport through traffic management with IoT. There is a little-explored potential for economic innovations, which meet the social needs that benefit the public management of cities. This trend improves management processes, methods and systems using technology and it is of interest to municipal governments and people, other studies of economic innovations that may arise in this research. In addition, our studies pave the way for others aligned with the digital change that has occurred today.

\section{RESEARCH PROCEDURES}

This research aims to identify trends in urban mobility projects from a patent study. Technometry uses statistical techniques to study the evolution of technologies (Coccia, 2005), this patent study relied on data from Espacenet, maintained by the European Patent Office. We collect data with Patent2net using a specific search term (Kumar and Mohanty, 2019). Using standard applications and routines makes data mining more effective (Ferraz et al., 2016). Due to the theory directing us to the theme "smart cities", these solutions seek to be sustainable and innovative, and our procedures are summarized in Figure 1.

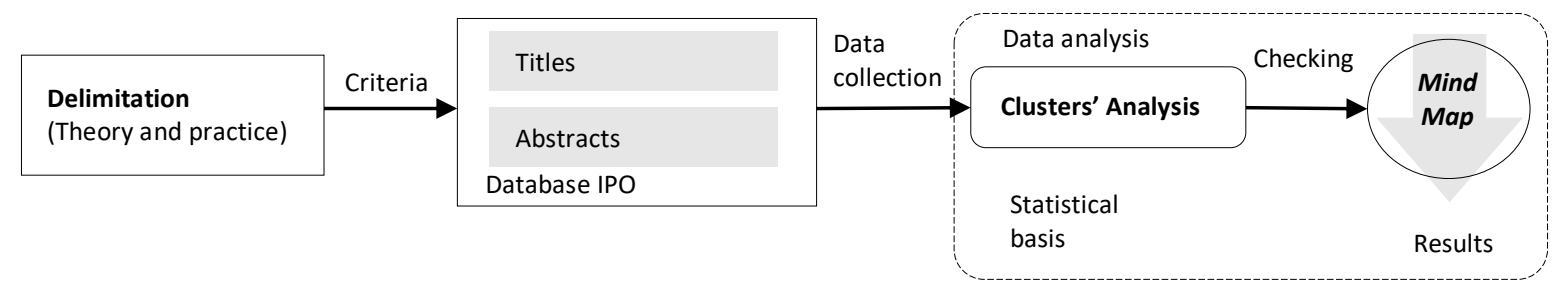

Figure 1. Research structure

The collection procedure applies Boolean logic to build the search expression appropriate to the identified theoretical and practical concepts. We used keywords associated with the theme urban mobility, management, and city, from the theoretical review, validated by the thesaurus, and we searched the results in Espacenet. Thus, the following search expression: (ta = management OR ta $=$ administration) $\mathrm{AND}((\mathrm{ta}=$ city $\mathrm{OR}$ ta $=$ urban) AND $(\mathrm{ta}=$ mobility OR ta $=$ transit $)$ ) was used in patent2net to mine data. Patents are mandatorily registered in the English language, which was adopted, resulting in 199 patents from the database.

To identify the driving innovation trends, we adopted the cluster by the k-means algorithm considers the frequency of words of abstracts (Maia, 2016) and the analysis of Goffman's zones, based on the hierarchy of the International Patent Code (IPC), which considers symbolic interpretation, creates interactions with different objectives and connects social and business interests (Mendonça and Simões, 2012; Manning, 2008). The tools of the Patent2Net application, developed on the R platform, organize the mining results for analysis (Reymond, \& Quoniam, 2016).

\section{RESULTS AND DISCUSSION}

Registered patents predominate in Asia, especially in China and South Korea, followed by India and Taiwan, which is justified by the geolocation of inventors and investors (Figure 2). Researchers in the Americas and Europe have patents registered in the United States, Brazil, France, Germany, the Netherlands, and Italy. Countries with a higher population density and with defined technological development policies generate more patents and investments of this nature. We verify the phenomenon overlapping maps and population density patents. The exception arises in Africa, where there are no conditions for the development of urban planning and technology for the phenomenon. In Brazil, the cases coincide with investments for the Olympic Games. 


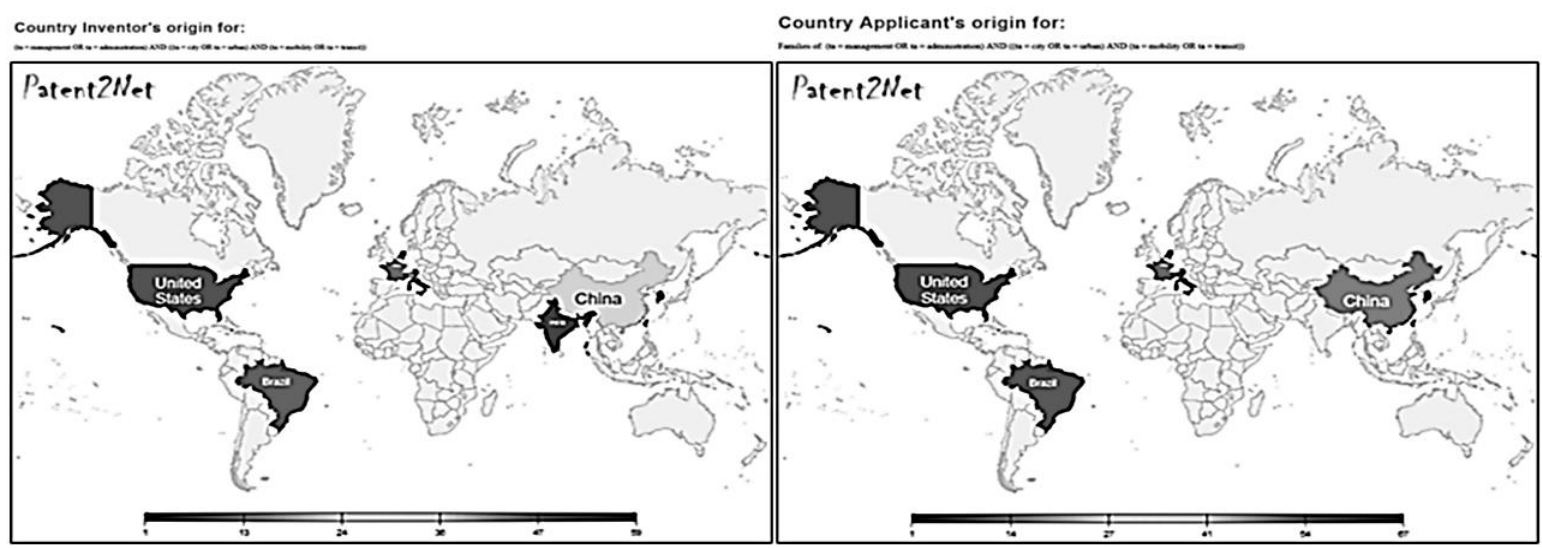

Figure 2. Geolocation Inventors and Applicants Map Source: Patent2Net Report

We classify patents according to their protection, designation A and A1 deals with investments with protection in the country of deposit. Patents designated as $U$ and $Y$ deal with similar utility inventions, but differing only in relation to the publication of patent documents issued after the first edition. Patents with worldwide protection receive the designation $\mathrm{W}$.

Utility patents receive the code $\mathrm{U}$ and $\mathrm{Y}$ if they are secondary. Utility patents enable economic innovations, that is, low cost. About $33 \%$ of total patent registrations are $\mathrm{U}$ or $\mathrm{Y}$, this volume of useful patents is significant and creates a potential for frugality. The development of technologies as proposed by Giffinger and Gudrun (2010) alters mobility, and affects the lives of people in cities, justifying the increase in registrations in the period from 2004 to 2019, with an emphasis on the year 2014, when we observe more growth accelerated.

The IPC allows the grouping of patents, so 113 occurrences deal with measures, methods, calculations, and signals, among others. The communication resources have 70 patents, construction infrastructure 12 and operational performance 38 patents. The Golfmann zone, by the IPC, has two well-defined groups that showed in Figure 3. One group gathers data from communication patents, the other specialized business process. The grouping of communication by the k-means method generated two groups, one for infrastructure and the other for dissemination processes; these groups defined in Table 1.
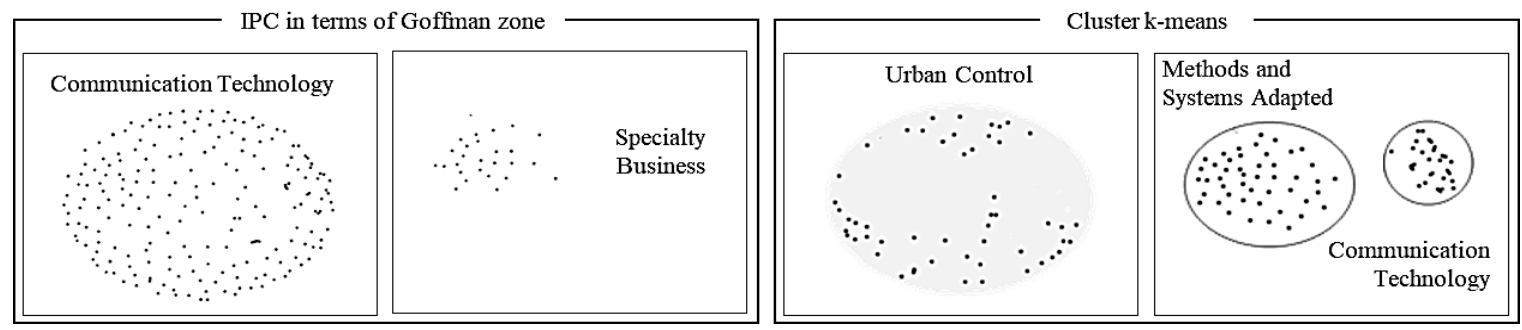

Figure 3. Clusters Results by k-means Algorithms and Goffman's Zone Source: Prepared by the author from Patent2Net Report

From the results, the communication presents two groups by the k-means that the IPC unifies. The innovation research proposed by Machado and Piccinini (2018) embraces this approach, with emphasis on 5G. This still makes urban control viable and the methods and systems as Bencke and Perez (2018) demonstrate, linking the concepts of communication and information and data systems. The theoretical basis of sustainability is adequate to associate the concept of monitoring and energy, which in the IPC finds a group proposed by smart cities as "clean energy". Machado and Piccinini (2018) address this aspect, as it affects the quality of life of citizens. In this sense, we see the results adhering to expectations.

The clusters converge to the use of sustainable and adaptive systems and processes, focused on mobility solutions for both methods. The proposition of Lom et al. (2016) shows the movement of digital transformation in the context of projects, which is increasingly present. The concept of smart cities points to connected cars, mobility management, digital education, wifi and 5G networks, communication systems, among others (Garau 
et al., 2015). This technological trend combined with the recent social context, in which we have undergone a technological revolution represented by industry 4.0 (Sarkheyli and Sarkheyli, 2019).

ICT connects equipment and people in essential transformations; however, this leads to other necessary innovations (Lom et al., 2013). The technologies show the business specialty by transposing communication technologies and focusing on the methods and systems developed for forecasting and supervision and customized utilities (Lom et al., 2016). Therefore, in line with Lom et al. (2016), patents predominantly respond to innovations in management and connectivity methods for urban mobility.

Table 1. Urban mobility patent grouping factors

\begin{tabular}{|c|c|c|c|}
\hline \multicolumn{2}{|c|}{ k-means algorithm } & \multicolumn{2}{|r|}{ Goffman zone (IPC) } \\
\hline $\begin{array}{l}\text { Communication } \\
\text { (Disclosure) }\end{array}$ & $\begin{array}{l}\text { Disclosure, } \\
\text { communication, wireless } \\
\text { communication, } \\
\text { technical, related. }\end{array}$ & \multirow[t]{2}{*}{ Communication } & \multirow{2}{*}{$\begin{array}{l}\text { Connected car, this disclosure, mobility } \\
\text { management, digital education, wireless } \\
\text { communication networks, communication } \\
\text { system, 5G communication, smart city, } \\
\text { relational outreach, intelligent building, } \\
\text { electrical communication technique wireless } \\
\text { smart home. }\end{array}$} \\
\hline $\begin{array}{l}\text { Communication } \\
\text { (Infrastructure) }\end{array}$ & $\begin{array}{lr}\text { Present r disclosure, } \\
\text { communication, wireless, } \\
\text { sitting, wireless } \\
\text { communication networks. }\end{array}$ & & \\
\hline \multirow[t]{2}{*}{$\begin{array}{l}\text { Methods and } \\
\text { systems } \\
\text { adapted }\end{array}$} & \multirow[t]{2}{*}{$\begin{array}{l}\text { Adapted administrative, } \\
\text { forecasting, methods } \\
\text { specially } r \text { adapted } \\
\text { systems, commercial, } \\
\text { financial management, } \\
\text { systems methods. }\end{array}$} & $\begin{array}{c}\text { Mobility } \\
\text { management }\end{array}$ & $\begin{array}{l}\text { Peak flow, management module, power } \\
\text { consumption, urban management, traffic } \\
\text { system, monitoring management, transit } \\
\text { station, mass transit, pole station } \\
\text { management unit, transit network structure } \\
\text { system, subway station. }\end{array}$ \\
\hline & & $\begin{array}{l}\text { Specialty } \\
\text { business }\end{array}$ & $\begin{array}{l}\text { The specific business sector, for the purpose } \\
\text { of systems methods, supervision systems } \\
\text { forecasting purposes, eg sector-specific } \\
\text { public services adapted. }\end{array}$ \\
\hline Monitoring & $\begin{array}{l}\text { Measurement, } \\
\text { monitoring, electric } \\
\text { power, communication, } \\
\text { power supply. }\end{array}$ & \multirow[t]{2}{*}{ Clean energy } & \multirow{2}{*}{$\begin{array}{l}\text { Power management, traction power, electric } \\
\text { power, measurement tests, power supply, } \\
\text { supply system, circuit arrangements, DC, } \\
\text { vehicles in general, electricity, vehicles } \\
\text { powered by electricity, energy transit. }\end{array}$} \\
\hline Energy source & $\begin{array}{l}\text { Electric, power supply, } \\
\text { power, system, module }\end{array}$ & & \\
\hline \multirow[t]{2}{*}{$\begin{array}{l}\text { Data and } \\
\text { information }\end{array}$} & \multirow[t]{2}{*}{$\begin{array}{l}\text { Passenger information, } \\
\text { public transport, bus, } \\
\text { module. }\end{array}$} & $\begin{array}{l}\text { Digital data } \\
\text { network }\end{array}$ & $\begin{array}{l}\text { Processing equipment, processing of digital } \\
\text { computer data line network, fingerprint } \\
\text { identification, digital data processing, } \\
\text { equipment especially methods. }\end{array}$ \\
\hline & & $\begin{array}{l}\text { Digital data } \\
\text { transmission }\end{array}$ & $\begin{array}{lll}\text { Technical transmission of } & \text { digital } \\
\text { information, eg transmitting } & \text { digital } \\
\text { information, eg telegraphic. } & & \end{array}$ \\
\hline Railway & $\begin{array}{lll}\begin{array}{l}\text { Railing, } \\
\text { insulation. }\end{array} & \text { steel rail, } \\
\end{array}$ & \multirow[t]{2}{*}{ Rail transport } & \multirow{2}{*}{$\begin{array}{l}\text { Railways to ensure security, monitoring } \\
\text { system, rail system, dispatch trains, urban } \\
\text { systems, transport railways, rail traffic. }\end{array}$} \\
\hline \multirow[t]{2}{*}{ Tracking } & \multirow{2}{*}{$\begin{array}{l}\text { Tracking, region, vehicle, } \\
\text { rail system vehicles. }\end{array}$} & & \\
\hline & & \multirow[t]{2}{*}{ Control } & \multirow{2}{*}{$\begin{array}{l}\text { Traffic control, road vehicles control } \\
\text { systems. }\end{array}$} \\
\hline \multirow[t]{2}{*}{ Urban Control } & \multirow{2}{*}{$\begin{array}{l}\text { Control, urban, passenger } \\
\text { monitoring, level station. }\end{array}$} & & \\
\hline & & $\begin{array}{l}\text { Smart shuttle } \\
\text { service }\end{array}$ & $\begin{array}{l}\text { Controller Carbone, public traffic controller, } \\
\text { fare collection, public transport personnel, } \\
\text { data acquisition, traffic management, bus } \\
\text { passenger, acquisition module input, } \\
\text { released model, connected output. }\end{array}$ \\
\hline
\end{tabular}

The frames by Goffman's zone shown in Figure 3 show the most defined grouping for communication technology and business expertise. This confirms the trend brought by the concept of smart cities and connectivity. Another technique (k-means) shows the trend of urban control processes and resources, adapted systems and methods and communication technologies. The other factors showed dispersed results, with no defined groupings. In k-means clusters, the communication factors (dissemination and infrastructure) treated as a single factor make the cluster denser, without changing its contour. This confirms the analysis of the factors 
obtained in both methods and marks the importance of communication in the two clustering techniques. Other better-defined clusters are those of adapted systems and methods and urban control (k-means) or business specialty (Goffman's zone). These attributes demonstrate another trend, which seeks process improvements, making them more flexible and versatile, which response to the speed of current social changes, driven by social networks and access to technology (Lom et al., 2016).

Although patented inventions refer to the idea of creating equipment, this research on urban mobility shows the importance of innovative and sustainable processes and systems, supported by ICT. The analysis finds theoretical support in smart cities, based on technologies and developments. There is a tendency to align digital transformations with urban mobility.

\section{CONCLUSION}

Our aim is to identify innovation trends in urban mobility, which we can apply in project definition, helps to explain how innovations are emerging. We can identify that there are two key aspects that research has been developing, one in terms of systems and the other in terms of processes, especially in relation to specific and adaptive processes and systems, which support the concept of digital transformation. Thus, there is an intimate relationship with social aspects, which involves more than the urban dynamics determining how people occupy cities, and transcends the context of urban mobility projects and innovations, reaching the domain of social sciences and their borders with other areas of knowledge.

The main limitation observed involves the patent registration process. Depending on the country and the nature of the investment, this registration may take. This aspect, as in the case of registrations in Brazil that are slow, can generate a delay in the perception of what is intended to be created. However, in the study, by aligning with other aspects, this limitation has part of its risks mitigated. This is especially so because it is in line with the references of smart city researchers.

Because about one-third of the results in utility patents, that is, type $U$ or $Y$, there is still the potential for frugality. This opens the way to discover inventions, making them more than mere records, creating conditions to improve the quality of life of people in cities.

\section{ACKNOWLEDGMENT}

We thank Fundo de Apoio à Pesquisa - FAP/UNINOVE for their research support.

\section{REFERENCES}

Bencke, L. R., \& Perez, A. L. F. (2018). Análise dos principais modelos de indicadores para cidades sustentáveis e inteligentes. Revista Nacional de Gerenciamento de Cidades, 6(37).

Coccia, M. (2005). Technometrics: Origins, historical evolution and new directions. Technological Forecasting and Social Change, 72(8), 944-979.

Dias, D., Amorim, J. H., Sá, E., Borrego, C., Fontes, T., Fernandes, P., \& Tchepel, O. (2018). Assessing the importance of transportation activity data for urban emission inventories. Transportation Research Part D: Transport and Environment, 62, 27-35.

Ferraz, R. R. N., Quoniam L., Reymond D., Maccari E. A. (2016) Example of open-source OPS (Open Patent Services) for patent education and information using the computational tool Patent2Net. World Patent Information.;46:21-31.

Forrester, J. W. (1970). Urban dynamics. IMR; Industrial Management Review (pre-1986), 11(3), 67.

Gakenheimer, R. (1999). Urban mobility in the developing world. Transportation Research Part A: Policy and Practice, 33(7-8), 671-689.

Garau, C., Masala, F., \& Pinna, F. (2015). Benchmarking smart urban mobility: A study on Italian cities. In International Conference on Computational Science and Its Applications (p. 612-623). Springer, Cham.

Giffinger, R., \& Gudrun, H. (2010). Smart cities ranking an effective instrument for the positioning of the cities? ACE: architecture, city and environment, 4(12), 7-26. 
Hashisaka Jr., C., and Patah, L. A., 2018. Mobilidade Urbana Inteligente: Um conceito em formação. Anais do VII SINGEP - Simpósio Internacional de Gestão de Projetos, Inovação e Sustentabilidade. São Paulo. Brasil.

Jürgens, B., \& Herrero-Solana, V. (2015). Espacenet, Patentscope and Depatisnet: A comparison approach. World Patent Information, 42, 4-12.

Kumar, D., \& Mohanty, M. N. (2019). A Survey: Classification of Big Data. In Cognitive Informatics and Soft Computing (pp. 299-306). Springer, Singapore.

Lom, M., Pribyl, O., \& Svitek, M. (2016, May). Industry 4.0 as a part of smart cities. In 2016 Smart Cities Symposium Prague (SCSP) (p. 1-6). IEEE.

Machado, L., \& Piccinini, L. S. (2018). Os desafios para a efetividade da implementação dos planos de mobilidade urbana: uma revisão sistemática. Revista Brasileira de Gestão Urbana, 10(1).

Maia, M. (2016). Produção científica em auditoria de informação: características do fenômeno da cauda longa e outros elementos de análise bibliométrica. Master's Dissertation. Universidade Federal do Paraná.

Manning, P. K. (2008). Goffman on organizations. Organization Studies, 29(5), 677-699.

Mendonça, R. F., \& Simões, P. G. (2012). Framing: different analytic approaches to a concept. Revista Brasileira de Ciências Sociais, 27(79), 187-201.

Moreira, S. T. B., Tonelli, D. F., Mesquita, I., Silva, S. R., \& Silva, M. O. (2016). Uma proposta de modelo analítico para a inovação na gestão pública. Revista do Serviço Público, 67, 59-84.

Pellicer, S., Santa, G., Bleda, A. L., Maestre, R., Jara, A. J., \& Skarmeta, A. G. (2013, July). A global perspective of smart cities: A survey. In 2013 Seventh International Conference on Innovative Mobile and Internet Services in Ubiquitous Computing (p. 439-444). IEEE.

Nesterova, N. (2017). City Logistics Living Labs-an ecosystem for efficient city logistics Nina Nesterova, Hans Quak, Tariq van Rooijen, Tom Cherrett 2, Fraser McLeod 2. In Research Day Conference proceedings 2017 (p. 30).

Reymond, D., \& Quoniam, L. (2016). A new patent processing suite for academic and research purposes. World Patent Information, 47, 40-50.

Sarkheyli, A., \& Sarkheyli, E. (2019). Smart Megaprojects in Smart Cities, Dimensions, and Challenges. Smart Cities Cybersecurity and Privacy, 269-277. doi:10.1016/b978-0-12-815032-0.00019-6 